\title{
AGRICULTURE AND ECONOMICS IN THE WATER FRAMEWORK DIRECTIVE:
}

\section{PROGRESS AND LIMITATIONS}

José A. Gómez-Limóna , Laura Riesgo

${ }^{a}$ Instituto de Investigación y Formación Agraria y Pesquera (IFAPA). Junta de Andalucía. Centro Alameda del Obispo, Apdo. 3092, Cordoba, Spain. josea.gomezlimon@juntadeandalucia.es

${ }^{\mathrm{b}}$ European Commission, Joint Research Centre (JRC), Institute for Prospective Technological Studies (IPTS), Edif. Expo, Avda. Inca Garcilaso, Seville, Spain. laura.riesgo@ec.europa.eu

\begin{abstract}
The agricultural sector is having an increasing impact on water resources in Spain, both from a quantitative (consumption) and qualitative (pollution) point of view. Therefore, the implementation of the Water Framework Directive (WFD) will have a deep impact on this productive sector. In fact, new river management plans are aiming to reduce these pressures through the implementation of programmes of measures. These instruments will impose new requirements (costs) on farming activities, and this lead to the adoption of more efficient and sustainable production methods. Within this context the aim of this paper is to analyse how this new planning process is being developed, especially focusing on the use of economical analysis in order to select the programme of measures affecting the agricultural sector.
\end{abstract}

Keywords: Water Framework Directive (WFD); Agriculture; Irrigation; Economic Analysis.

\section{Resumen}

La agricultura es uno de los sectores que ejercen mayores presiones sobre las masas de agua en España, tanto de tipo cuantitativo (consumo) como cualitativo (contaminación). Tal circunstancia hace que éste sea uno de los sectores más afectados por la aplicación de la Directiva Marco del Agua (DMA). Así, los nuevos planes hidrológicos van a incluir programas de medidas encaminados a reducir tales presiones. Todo ello se traducirá en nuevas exigencias (costes) para este sector primario, lo que indudablemente se traducirá en nuevas formas de producción más eficientes y sostenibles. Dentro de este contexto, el principal objetivo de este artículo es analizar las diferentes etapas para el desarrollo del actual proceso de planificación hidrológica, haciendo especial hincapié en el uso del análisis económico en la selección del programa de medidas que afectará a la agricultura.

Palabras clave: Directiva Marco del Agua (DMA), Agricultura, Riego, Análisis económico. 


\section{INTRODUCTION}

In October 2000, Directive 2000/60/EC of the European Parliament and of the Council establishing a framework for community action in the field of water policy, or in short the Water Framework Directive (WFD), was adopted. The WFD aims to prevent further deterioration and enhance the status of aquatic ecosystems as well as to promote sustainable water use. These objectives are being pursued at river basin district level as the main unit for management of river basins in every Member State, through the River Basin Management Plan (RBMP). These plans should be based on the analysis and evaluation of the impact of human activity on the status of water resources. Thus, specific measures at river basin level need to be defined and implemented for the achievement of "good status" of water resources. In order to design the RBMP, Member States are required to specify the geographical coverage of the river basin districts, providing a list of competent authorities for each district (responsible for the design and implementation of the management plan) as well as to ensure the participation of the general public during the planning process.

Implementation of the WFD demands important changes in water management policy. This is especially true for Mediterranean countries, where the adaptation to the WFD requirements has a greater impact due to their specific climatic characteristics such as aridity, an uneven distribution of water resources, drought and flood episodes, water management based on water supply policies, and an agricultural sector responsible of about $70 \%$ of total water use.

The WFD takes into account Economics as a key discipline to achieve the good status of water resources. This is an important novelty in this Directive, as economic analysis has been included in water policy as a tool to help with water management decision-making to achieve an integrated water resource management system and a sustainable use of water resources. Furthermore, economics instruments (for example, water pricing) have also been considered as options to be implemented in order to achieve the WFD objectives.

Activities affected by the economic analysis in the implementation of the WFD are included in Table 1. Two stages are identified in the implementation process. First, a finished stage includes the economic analysis of water use, a long-term forecast of water use scenarios (art. 5) and the analysis of the recovery of the costs of water services (art. 9 and Annex III). The second stage is the adoption of the Programme of Measures (PoM) as the core of the RBMP, where all instruments required to achieve the good status of water bodies are collected.

Table 1: Use of economic analysis in the Water Framework Directive.

\begin{tabular}{|c|c|c|}
\hline Articles & Activities & Economic analysis method \\
\hline Art. 5 & Characterisation of water uses & $\begin{array}{l}\text { Regional analysis } \\
\text { Prospective analysis }\end{array}$ \\
\hline Art. 9 and Annex III & Estimates of the recovery of costs & $\begin{array}{l}\text { Cost accounting } \\
\text { Public funding }\end{array}$ \\
\hline $\begin{array}{l}\text { Art. 11, Annex III and Art. } \\
5\end{array}$ & $\begin{array}{l}\text { Selection of measurements by cost- } \\
\text { effectiveness analysis }\end{array}$ & Cost-effectiveness analysis \\
\hline Art. 4 & Reasons to define disproportionate costs & Cost-benefit analysis \\
\hline
\end{tabular}


Results from the first stage of the implementation of the WFD are available for each river basin district as well as in the summary published by the MIMAM (2007a and 2007b). Preliminary results from the second stage are included in the Outline of Main Topics (OMT), as is shown in the next section.

The WFD establishes a wide set of activities and issues to be included in the RBMPs, most of them being interdependent. In consequence the development of these plans has become a complex procedure. The main aim of this paper is to explain how the economic analysis implemented for this planning process is being developed in Spain, pointing out the implications for Spanish irrigated agriculture.

After this introduction, section 2 presents Spanish legislation to regulate the RBMPs. Section 3 includes the objectives, contents and the procedure to develop the RBMP as well as the PoM. Section 4 analyses the implications of these plans for irrigated agriculture. Finally conclusions are drawn in Section 5.

\section{NEW RIVER BASIN MANAGEMENT PLANS IN SPAIN}

\subsection{Water sector and irrigated agriculture in Spain}

Due to its predominantly Mediterranean semi-arid conditions, the water sector in Spain has traditionally been a strategic sector to cover society's basic needs (drinking water and food). In this sense the main purpose of public and private initiatives has been the increase of the amount of usable water by building dams and other water infrastructures. This process was especially developed during the $20^{\text {th }}$ Century when a plethora of water investments were built up. This explains why Spain is nowadays the Member State within the European Union with the most irrigated land (3.5 million hectares, about 14\% of national utilized agricultural area) and why this kind of agriculture is the main water user, consuming $75 \%$ of all water resources used $17,780 \mathrm{hm}^{3} /$ year of the total $23,250 \mathrm{hm}^{3} /$ year) (INE, 2009).

However, it is worth mentioning that the irrigation sector is Spain is highly heterogeneous. In brief, two main irrigated systems can be defined (Gómez-Limón, 2008). The first one is located in inland regions (Duero, Ebro or Guadiana basins) accounting for about 1.5 million hectares $144 \%$ of Spanish irrigation). This is mainly devoted to extensive annual crops such as cereals, fodder and industrial crops (sugar-beet, sunflowers, etc.). This productive orientation is justified both for agroclimatic reasons (continental climate conditions) and for the important institutional support received (public investments in irrigation infrastructure and traditional production-driven agricultural policies). In any case these extensive irrigation systems have been possible because of the relatively abundant availability of land and water as their main inputs, and the productive techniques progress (mechanization and agro-chemistry) that has allowed the management of the large plots of lands to be transformed into irrigated land. However, this system is characterized by its low profitability levels, and high dependence on public support provided by agricultural policy.

The second most important irrigated system in Spain is the intensive horticultural production located in Mediterranean regions (Segura, Júcar and other minor Mediterranean basins), accounting for 800.000 hectares $124 \%$ of total irrigated lands). Because of the mild climate, citric and tropical fruit crops are possible, and annual crops (vegetables) can be harvested much earlier than in standard European conditions, reaching higher 
market prices. Furthermore, using advanced technology (greenhouse production), several harvests can be achieved annually for most vegetable crops. All these features make these irrigated farming activities highly profitable, being competitive in international markets without any public support. However, the main weakness of this irrigated system is the scarcity of water resources and the increased demand for water from competitive sectors, like tourism (hotels, resorts, water related leisure activities, e.g. golf and spas), that is jeopardizing water used for agricultural purposes.

\subsection{The Spanish legislation}

The WFD was transposed to Spanish legislation by Article 129 of Act 62/2003, the Accompaniment Act of the State general budget for 2004. The WFD's transposition to Spanish legislation was hurried due to the short transposition timetable included in the European directive. In any case, it is worth highlighting that the Accompaniment Act of the State general budget transposed, in a literal way, those issues necessary for it to be considered an Act. Other subjects were not necessary, and they were postponed to later normative developments. In any case, this transposition involved important amendments to the Spanish Water Act.

To complete the WFD transposition some subsequent regulations were necessary. In this sense the Regulation on River Basin Management Planning (RRBMP) was approved by Regulation 907/2007, completing the legal framework on water management planning required by the WFD. The RRBMP set up the mandatory contents of new RBMPs, as well as the development and endorsement procedure. However, due to technical difficulties in the development of RBMPs (plenty of interdependent activities and issues) an Instruction on River Basin Management Planning was also approved by Ministerial Order ARM/2656/2008. The aim of this instruction is to present technical criteria to homogenize and systematize RBMP development for each Spanish river basin district according to the RRBMP.

\subsection{Timetable of the new river basin management plans}

The approval of the Spanish legislation on river management planning in July 2007 meant a new stage for water policy, that should have been finished by 29th December 2009, the deadline fixed by the WFD to publish the new RBMPs. However, as pointed out below, the process of approval of new RBMPs in Spain has been delayed, and to date (August 2010) no single plan has yet been published.

The full implementation of this procedure requires a set of documents to be completed in every district. First, a report on the characterization of the river basin district must be presented. This study is an updated version of a preceding report on the characterization of river basin districts done earlier in accordance with Articles 5 and 6 of the WFD, presented to the European Commission in July 2005. This report includes: a) a general description of the characteristics of the river basin districts, b) a summary of significant pressures and impacts of human activity on the status of water, and c) an economic analysis of water use. Secondly, a report on the work programme, timetable and consultation measures has also to be prepared. This document contains the following topics: a) mandatory timetable and main stages and issues in the development of RBMPs, b) contents and scope of the documents included in the RBMP, c) public participation implementation during the planning process, and d) endorsement and updating of the plans. Third and last, a report on public participation is also required, in order to 
establish the procedure to ensure public participation in the development of the RBMP.

These three reports were published by the competent authorities of each district (i.e., hydrographic confederations in the cases of interregional basins or regional water agencies for intra-regional basins) in the first semester of 2007. A comprehensive summary of the reports of all Spanish basins can be found in MIMAM (2007b). These documents were submitted for public consultation for 6 months (from July 2007 to February 2008) and are still available on the websites of the river basin districts. As a result of this process several comments were received and discussed, and finally some of them were included in an updated version of these reports.

The next stage in the development of the plan was the elaboration of a Provisional Outline on Main Topics (POMT) by river basin districts' authorities. This report is an intermediate stage between the characterization of the river basin districts and the RBMP, which aims to set out the main issues to be tackled in the plan. This report includes: a) an identification of main pressures and impacts on the status of water bodies, identifying those sectors and activities as being at risk of failing to meet the environmental objectives, and b) the requirements for the achievement of the environmental objectives, in order to choose the most suitable policy instruments to be included in the PoM.

POMTs were finished in most of the Spanish river basin districts in July 2008, and were available for consultation on the websites of the river basin districts' authorities. These documents were also under consultation for comments from the public for 6 months. After public consultation, the final Outline on Main Topics (OMTs) of each district were also published as an updated version of previous POMTs.
The planning process is still ongoing at the present time (August 2010) with the development of the Provisional River Basin Management Plan (PRBMP) by the authorities of river basin districts'. Once this document is approved (probably within a few months) it will be submitted to all interested agents for comments during a 3-month period. At the same time, copies of the PRBMP will be under public consultation through the websites of river basin districts' authorities for 6 months. Taking into consideration comments, suggestions and proposals, the authorities of the river basin districts will prepare a report trying to incorporate them in the updated PRBMP. The updated PRBMP will then be submitted to the District's Water Council and the Competent Authorities Committees for its approval. Finally, the updated PRBMP will be sent to the Ministry of Environment and Rural and Marine Affairs to be legally approved by the Spanish Government as the new RBMP.

Taking into account the current state of the planning process, it is obvious that the deadline fixed by the WFD (29th December 2009) cannot be reached ${ }^{2}$. In fact, due to the requirement for public consultation and other legal processes, it is probable that the new approval plan will not be achieved until the second semester of 2011 . Because of this, RBMPs are still not known and their impact on the Spanish irrigation sector cannot be

\footnotetext{
${ }^{1}$ In August 2010 only some intra-regional basins (Balearic Island, Andalusian Mediterranean, Guadalete and Barbate rivers, Tinto, Odiel and Piedras rivers and Catalunya districts) have made public their PRBMPs. The PRBMPs of the larger interregional districts, that cover more than $80 \%$ of Spanish territory, have still not yet been approved. They are expected to be published by autumn 2010.

${ }^{2}$ On July 2010 ten other Member States have also presented their RBMP (Belgium, Cyprus, Denmark, Slovenia, Greece, Ireland, Lithuania, Malta, Poland, Portugal and Romania). Spain and these other ten states have already received an initial warning from the European Commission for not fulfilling the WFD requirements.
} 
assessed. In any case in this paper we discuss the previous documents generated within the Directive implementation process, trying to anticipate how the future RBMPs could affect this productive sector.

Finally, it is worth mentioning that RBMPs will need to be updated every 6 years after being approved to ensure compliance with the WFD. In this sense, an update of the RBMPs will be required before 29th December 2015, 29th December 2021, etc. These updates will be based on a report describing the progress in the implementation of the RBMP taking into account the monitoring of the status of water bodies. Thus, the updating of RBMPs may be seen as a cyclical and recurrent process.

\section{RIVER BASIN MANAGEMENT PLANS AND THE PROGRAMMES OF MEASURES}

\subsection{River basin management plans: objectives and} contents

As fixed by the WFD, the main objectives of the RBMPs are: a) the achievement of good status and the necessary protection for water bodies, b) the satisfaction of water demands, c) the harmonization of regional and sectoral developments with the environmental protection, and d) the mitigation of the effects of floods and droughts. To achieve these objectives the RBMP should promote sustainable water use based on integrated management and long-term protection of available water resources.

As established under the RRBMP, Spanish management plans need to be adjusted to the following guidelines of contents:
1. A general description of the characteristics of the river basin districts.

2. A general description of water uses, impacts and anthropogenic pressures on the status of water bodies.

3. Monitoring networks established for the evaluation of the status of water bodies.

4. A list of the environmental objectives for every water body and a timetable for their achievement. Furthermore, a list with the exemptions considered and the extensions of deadlines is required.

5. A summary of the economic analysis of water use.

6. A summary of the PoM planned to achieve the environmental objectives.

Although these plans have an integrative perspective of water management joint consideration of all water uses), it is worth remarking that for the Spanish basins irrigated agriculture is a key issue (see Section 2.1). This fact will be clearly shown in Section 4, where the impact of the WFD on this sector is analysed.

\subsection{Environmental objectives and the pro- grammes of measures}

As was mentioned above, the management planning established under the WFD reinforces the environmental objectives to be achieved through RBMPs. In order to make these objectives operative, the implementation of the RBMPs requires the approval of a list of the concrete environmental objectives for each water body, including the timetable to achieve those objectives. Usually, these concrete objectives aim to achieve a “good status" by 2015.

To meet the requirement mentioned above, water authorities need to carry out a characterisation of the current status of water bodies as well as the foreseeable impact on this status of already approved related programmes or plans. This study 
allows long-term forecasting of the status of water up to 2015 . Therefore the bodies of water with a bad status at present and also those at significant risk of failing to meet the good status in 2015 will be the targets of the measures to be included in the RBMPs through their respective PoMs.

A "measure" is defined as any tool to achieve the environmental objectives established in the RBMP. The aim of measures is to reduce the gap between the current or the forecasted status of the bodies of water and the good status previously set as the objective.

Environmental objectives to achieve good status of water bodies are mandatory, but some exemptions can be considered. Article 4 of the WFD establishes that some of the environmental objectives could not be reasonably achieved for reasons of "technical feasibility" or "disproportionate costs". Under such circumstances less stringent environmental objectives can be defined by 2015 , postponing in this way the deadline to achieve the good status up to a maximum of two further updates of the RBMP, i.e. until 2027. The establishment of alternative objectives and the reasons for it should be specifically explained and justified in the RBMP on the basis of technical, socioeconomic and environmental data, as is commented below.

\subsection{Designing and making operational the pro- grammes of measures}

In order to design the PoM, planners need to take decisions based on the implementation of the cost-effectiveness principle, that is to say the achievement of the environmental objectives established at a minimum cost. In this sense, the Cost-Effectiveness Analysis (CEA) is proposed by the RRBMP to rank the list of alternative measures considered to achieve the environmental objectives taking into account the ratio between the equivalent annual cost and the reduction of impacts or pressures. According this lexicographic order, it is possible to minimize the financial cost to achieve the environmental objective established for each body of water (Kranz et al., 2004; MARM, 2009a and 2009b). In any case, some doubts have arisen about this methodology. First, as pointed out by Berbel et al. (2009), the lexicographic approach applied in the CEA does not allow the analysis of trade-offs between environmental and social objectives. Furthermore, as explained by Aulong et al. (2009), considering average cost as proposed for the CEA implementation does not guarantee the selection of minimum cost alternatives. In order to improve the analysis, public participation and decision-making, MartínezAlier et al. (1998) propose the multi-criteria valuation as the most suitable approach to cope with this analysis.

The achievement of the environmental objectives may be exempted for two reasons: a) the presence of disproportionate costs taking into account the financial capacity to fulfil the WFD objectives, or b) the presence of disproportionate costs balanced to the benefits of the environmental improvement. First, the financial capacity problem depends on the contribution made by the various water uses to cover the costs of the management plan in the river basin districts. However, as explained by Gómez (2006), this problem should be considered just to extend the deadline to achieve the environmental objectives, not to relax the proposed environmental objectives. In fact, only in cases where the costs would override the benefits of achieving a good status of water bodies should less stringent environmental objectives be set.

In order to reasonably justify those exemptions in the presence of disproportionate costs, Postle et al. (2004), Del Saz-Salazar et al. (2009) 
and Martin-Ortega et al. (2009) show that the most suitable economic technique is the CostBenefit Analysis (CBA). However, as was pointed out by Berbel et al. (2009), the approaches followed by the Member States for the implementation of the WFD in this sense do not use this technique. Usually the strategy followed is the proposal of a simple indicator to identify the presence of disproportioning costs such as an economic indicator, e.g. loss of income greater than $20 \%$, or a social indicator, e.g. employment falls by more than 10\% (see also Maestu and Berbel, 2009).

Once the management plans are approved, river basin districts should ensure that the measures included in the RBMPs are implemented. However, the PoMs may enclose measures which the river basin districts have no authority to implement. In these particular cases, these measures should be implemented by the competent administration. Due to this circumstance, the implementation of RBMPs will be a joint responsibility among river basin districts and other authorities, in particular regional departments (authorities for the implementation of agricultural and environmental policies) and local authorities responsible for urban water supply.

Despite the coherence and technical validity of the legislation to implement the PoMs (RRBMP), its practical execution may have some problems. The current institutional arrangement for the implementation of the water policy in Spain is probably the main drawback for the approval of the RBMPs and their future execution, in particular in the case of inter-regional river basin districts, where agreement among different autonomous regions is needed. In fact, it is highly probable that in a near future territorial conflicts (between autonomous regions, or even between more reduced territories) and social tensions (e.g. between farmers and environmental organizations) become even more acute. Within this context policy agreements in the Competent Authorities Committees will be extremely difficult to be achieved, resulting in further delays in the approval of the RBMPs.

\section{RIVER BASIN MANAGEMENT PLANS AND IRRI- GATED AGRICULTURE}

To analyse the foreseeable consequences of the new RBMPs on irrigated agriculture it is of interest to review the documentation produced during the planning process until now, particularly OMTs. As commented in section 2.3, OMTs include those issues (water bodies and sectors) identified as being at risk of failure to achieve the plan objectives. Therefore these topics are the ones to be compulsorily tackled within RBMPs and their PoMs. This documentation also contains a list of alternative measures to be considered for the achievement of the environmental objectives.

\subsection{Main topics facing irrigated agriculture}

The OMTs of the river basin districts classify the "main topics" in four thematic categories: a) failure to achieve the environmental objectives, b) satisfaction of water demand and sustainable use, c) protection against extreme climatic events, and d) knowledge and governance. Given that irrigated agriculture is the main user of water in most Spanish river basin districts, all these topics are involved with this kind of farming. Next, these main topics are reviewed.

\section{Failure to achieve the environmental objectives}

Three agricultural pressures were identified as originating the greatest impacts on water resources, risking the achievement of the environmental objectives: 
1. Excessive river flow reduction. Large abstractions of fresh surface water to satisfy the consumptive demand of irrigated agriculture result in reductions and changes in the natural flow regimes of rivers.

2. Excessive abstraction on aquifers. Many groundwater bodies are affected by high abstraction rates from irrigated agriculture. This excessive abstraction results in a reduction of the piezometric level and in significant damages to linked terrestrial ecosystems (e.g. wetlands) as a consequence.

3. Diffuse source pollution. Agriculture is a diffuse source of pollution caused by surface run-offs and drainage of nutrients (mainly nitrates and phosphates used as fertilizers) and phytosanitary products used to control pests and diseases.

All these topics are shared by most of the river basin districts in Spain. However, the intensity of environmental externalities caused by irrigation strongly varies depending on the regions. In this sense, it is worth pointing out that irrigated farming is more problematic in the Mediterranean regions (i.e. Segura, Júcar Andalusian Mediterranean or Guadalquivir districts). In these territories, because of their climatic conditions, are concentrated the most intensive farming activities in Spain (vegetable and fruit production), involving the highest irrigation water and chemical consumption rates (Gómez-Limón, 2008). This is why in this area water problems, both quantitative and qualitative, are more acute.

\section{Water demand satisfaction and sustainable use}

Increasing pressure from the continuous growth in water demand in all economic sectors is causing quantitative problems /current aggre- gated demands are already larger than available water resources in more "mature" Spanish districts). This situation means that many irrigated areas do not receive the amount of water fixed in their water rights due to a structural water deficit.

This problem will probably be aggravated in the near future because of the implementation of river flow regimes (also known as "ecological flow") included in the new RBMPs. In order to achieve a good status of water bodies, new water plans will make it compulsory that a minimum flow of water be available in all rivers at any time. Thus, this new ecological demand for water will likely increase competition for available water resources, increasing water deficits. Within this framework, the irrigation sector will probably be the most affected one because of its relatively lower profitability. This is especially true for the Mediterranean regions, where water deficits are already considerable /due to the increasing demand for agriculture, urban consumption and tourism activities).

In any case it is worth mentioning that there are new plans to transform some rain-fed agricultural lands into irrigation for 2015. For instance, in the Ebro basin 231,000 new hectares of irrigated land are planned for this time horizon, 149,740 hectares in the Duero basin, 31,000 hectares in the Guadalquivir basin, etc. Obviously, this circumstance could cause even more problems in this sense, particularly in more "mature" basins such as the Guadalquivir. All these facts demonstrate the necessity for an in-depth analysis of sustainable water resource availability, prior to the approval of RBMPs, where these new demands are included. Thus, only in districts where new water supply is reliable enough, should new changes to irrigated land be considered. Furthermore, in order to include in these plans new expansions of irrigated land, foresight studies about 
farming activities' profitability should be welcomed (Riesgo and Gómez-Limón, 2006). In this sense, agricultural market/policy scenarios could be key issues to determine which new irrigation plans are really worth implementing.

\section{Severe weather events (droughts)}

Droughts are climatic, natural and temporary events registered in a prolonged and unusual dry period causing water scarcity. These events are particularly recurrent in Mediterranean basins, resulting in a significant reduction in the availability of water resources and the consequent difficulty to satisfy water demands and ecological flows.

Although these situations impact on all water uses, increasing temporally quantitative and qualitative water problems, the agricultural sector is normally the most affected because it is the main water consumer and the least relatively profitable activity competing for the scarce resources.

\section{Knowledge and governance}

Faced with the development of the RBMPs, competent authorities are dealing with two main drawbacks. First, the lack of reliability in the assessment of basic and sensitive data may affect the evaluation of the status of the bodies of water. This lack of technical knowledge has an effect on the following issues: a) assessment of available water resources, b) water uses and abstractions, c) irrigation efficiency and return flows from agriculture, and d) presence of water uses without water rights. Secondly, weakness in governance or in management capacity is also worth mentioning. This may be reflected in: a) multiplicity of administrations on water management that may result in a lack of coordination and discredit of the river basin districts, b) weakness of control in water rights concessions and c) limited administrative capacity which results in large delays to sort out procedures.

\subsection{Alternative acting strategies}

As explained above, in the OMTs have been included some alternative measures that may be implemented to face the problems mentioned in the previous section. Among these strategies, those related to irrigated agriculture are briefly presented next.

In order to avoid excessive abstractions of surface water and groundwater, to satisfy water demands and to mitigate drought effects, some key measures are being studied:

- Irrigation infrastructure modernization to increase technical efficiency: improvements in distribution channels and pipelines, replacement of surface irrigation by sprinkler or drip irrigation, etc.

- Economic instruments: updated water pricing for irrigation /controls on abstractions of water by individual users and volumetric water pricing) and legislative amendments to improve water markets /water rights transfers and public acquisition of water rights).

- Increase public control on irrigation water use: increase staff to monitor water abstractions, replacement of individual abstractions by collective abstractions on groundwater, etc.

- Improve agricultural practices regarding irrigation: implementation and use of advisory systems for irrigators, implementation of more stringent and widespread codes of agricultural good practice, linking agricultural subsidies with the environmental performance of irrigated farms, etc. 
- Limit irrigation water availability: adjustment of existing water concessions and irrigation land decrease when they do not fulfil basic environmental conditions.

- Increase water conservation through the construction of new dams, water recycling and reuse and the construction of desalination plants.

In order to limit diffuse source pollution other complementary measures are also being analysed:

- Promote a reduction in the number of fertilizers and phytosanitary treatments (more stringent and compulsory codes of agricultural good practices).

- Promote the use of fertilizers and phytosanitary products less harmful to the environment (ban those with more toxic active matters).

- Promote environmental checkups in irrigated farms/districts, including quality controls of irrigation return flows.

The implementation of a combination of these measures should make possible the achievement of environmental objectives at a minimum cost (CEA implementation). However, the selection of the measures to be included in the PoM is not an easy task. Many difficulties arise when planners are trying to estimate the costs and the effectiveness of each particular measure (Bateman et al., 2006; Birol et al., 2006; Hanley et al., 2006 and Martin-Ortega and Berbel, 2009). This difficulty is even larger if uncertainty (Siegel et al., 2010) or synergic effects between measures (Berbel et al., 2009) are also taken into account.

As has been explained, most of the difficulties to design RBMPs are due to the lack of information regarding irrigated systems and the deficient governance capacity of public bodies in charge of irrigation water management. This is why it is compulsory to include within PoMs measures to improve knowledge and governance. Only with the implementation of measures focused on the production of consolidated information media and the development of more efficient processes of institutional dialogue and public participation, will the next planning cycles be able to apply the WFD criteria with a more realistic basis.

In any case it is worth mentioning that the academic community in Spain has developed a large amount of work in order to analyse the multidimensional effects of the measures pointed out above. For a comprehensive summary of all the literature from the last two decades, the collective book coordinated by Gómez-Limón et al. (2009) is recommended. This background would be worth considering with the aim of more justified decision-making when designing the RBMPs and their PoMs.

\section{CONCLUSIONS}

The WFD implementation demands the design of new water plans for river basin districts (RBMPs). The objectives of these plans are the achievement of good status of the water bodies, satisfaction of water demands and a balanced socio-economic development and environmental protection. The design of these plans started in 2007 with the production of the first documents on the planning process. Following this process, the Outlines of Main Topics (OMTs) were produced in 2009. The next stage is the presentation and approval of the RBMPs, which will probably be published by the second semester of 2011 . This timetable involves a delay of two years regarding the deadline fixed by the WFD.

The implementation of the programmes of measures to be included in the RBMPs will have 
greater impacts on irrigated agriculture, especially those where the more serious water problems exist, both from a quantitative /scarcity of water resources) and a qualitative (pollution of bodies of water) point of view. Although all irrigated areas in Spain share these same problems, they are more acute in the Mediterranean regions, where water deficits and externalities (diffuse pollution) caused by the intensive water and agrochemical use are much larger.

In order to achieve the good status of the water bodies, alternative measures are being studied to be included in the programme of measures within the new RBMPs. The ones most related to irrigation farming are the improvement of irrigation efficiency, the implementation of economic instruments (water pricing and water markets), the promotion of adapted agricultural production (irrigation land and crops requiring less water) and the improvement in the use of agrochemicals. A combination of these measures based on a costeffectiveness analysis is expected to achieve the environmental objectives at minimum cost by 2015.

In any case the implementation of this combination of measures will probably impose new costs for irrigated agriculture, and as a consequence new efficient and sustainable production methods (technological and production changes) will necessarily be adopted. In this sense, the implementation of the WFD is a great challenge for the Spanish irrigation sector, as in many of the cases the achievement of the good status of the water bodies is a conflicting objective compared with the economical and social development of rural areas where this kind of farming is located. Thus, the design of the programmes of measures should be considered a compromise planning exercise aiming to achieve at the same time the environmental objectives proposed and the eco- nomic viability of the irrigated rural areas. For this purpose, it is expected that new RBMPs will include less stringent environmental objectives for those irrigated lands located in the Mediterranean regions of Spain with significant environmental damages (disproportionate costs argument), and some exemptions to the principle of cost recovery of water services for inland irrigated areas laffordability argument). Taking this into account, new river management plans should be understood as a recurrent process to achieve environmental objectives without jeopardizing the economic and social viability of economic activities such as irrigation.

\section{REFERENCES}

Aulong, S.; Bouzit, M. and Dörfliger, N. (2009), Integrating water balance and cost-effectiveness analysis for water management: An application in Jordan and Lebanon. Water Resources Management, 23: 731-753.

Bateman, I.J.; Brouwer, R.; Davies, H.; Day, B.H.; Deflandre, A. and Falco, S.D. (2006), Analyzing the agricultural costs and non-market benefits of implementing the Water Framework Directive. Journal of Agricultural Economics, 57(2): 221-37.

Berbel, J.; Mesa, P. and Martín Ortega, J. (2009), El análisis coste-eficacia en los programas de medidas de la $D M A$, in Gómez-Limón, J.A.; Garrido, A.; Calatrava, J.; Sáez, F.J. and Xabadía, A. (coords.) La economía del agua de riego en España. Fundación Cajamar, Almeria, pp. 55-73.

Birol, E.; Karousakis, K. and Koundouri, P. (2006), Using economic valuation techniques to inform water resources management: a survey and critical appraisal of available techniques and an applica- 
tion. Science of the Total Environment, 365(1-3): 105-22.

Del Saz-Salazar, S.; Hernández-Sancho, F. and SalaGarrido, R. (2009), The social benefits of restoring water quality in the context of the Water Framework Directive: A comparison of willingness to pay and willingness to accept. Science of the Total Environment, 407: 4574-4583.

INE, Instituto Nacional de Estadística (2009), Encuesta sobre el uso del agua 2007. INE, Madrid.

Gómez, C.M. (2006), Los costes y beneficios ambientales en el proceso de decisión de la DMA. Hydronomic Convention. Barcelona.

Gómez-Limón, J.A. (2007), DMA y agricultura. Cuestiones económicas, ambientales, sociales $y$ territoriales. Ingeniería y Territorio, 80: 56-63.

Gómez-Limón, J.A. (2008), El regadío en España. Papeles de Economía Española, 117: 86-109.

Gómez-Limón, J.A. (2009), Implicaciones de la nueva planificación hidrológica para la agricultura de regadio, in Gómez-Limón, J.A.; Garrido, A.; Calatrava, J.; Sáez, F.J. and Xabadía, A. (coords.) La economía del agua de riego en España. Fundación Cajamar, Almeria, pp. 22-53.

Gómez-Limón, J.A.; Garrido, A.; Calatrava, J.; Sáez, F.J. and Xabadía, A. (coords.) (2009) La economía del agua de riego en España. Fundación Cajamar, Almeria.

Hanley, N.; Wright, R. and Álvarez-Farizo, B. (2006), Estimating the economic value of improvements in river ecology using choice experiments: an application to the water framework directive. Journal of Environmental Management, 78: 183-193.
Kranz, N.; Görlach, B.; Interwies, E. (2004), Making the Right Choice - a Methodology for Selecting Cost-Effective Measures for the Water Framework Directive. Journal for European Environmental \& Planning Law, 1(3): 228-233.

Maestu, J. and Berbel, J. (2009), Financiación de servicios de agua y la aplicación de excepciones al principio de recuperación de costes, in Embid, A. (ed.) Régimen económico-financiero del agua. Los precios del agua. Civitas, Madrid, pp. 36-51.

MARM, Ministerio de Medioambiente y Medio Rural y Marino (2009a), Guía técnica para la caracterización de medidas. MARM, Madrid.

MARM, Ministerio de Medioambiente y Medio Rural y Marino (2009b), SICMACE: Sistema de información para la Caracterización de Medidas para el Análisis Coste-Eficacia. MARM, Madrid.

Martínez-Alier, J.; Munda, G. and O’Neill, J. (1998), Weak comparability of values as a foundation for ecological economics. Ecological Economics, 26: 277-286.

Martin-Ortega, J. and Berbel, J. (2009), Beneficios y costes ambientales en la Directiva Marco del Agua: conceptos y estimación. Revista de Estudios Geográficos, LXIXM: 577-607.

Martin-Ortega, J.; Berbel, J. and Brouwer, R. (2009), Valoración económica de los beneficios ambientales sin mercado derivados de la mejora de la calidad del agua: una estimación en aplicación de la Directiva Marco del Agua al Guadalquivir. Economía Agraria y Recursos Naturales, 9: 6589.

MIMAM, Ministerio de Medio Ambiente (2007a), El agua en la economía española: Situación y perspectivas. Informe integrado del análisis económico 
de los usos del agua en España. Artículo 5 y Anejo III de la Directiva Marco de Agua. MIMAM, Madrid.

MIMAM, Ministerio de Medio Ambiente (2007b), Planificación hidrológica. Síntesis de los estudios generales de las demarcaciones hidrográficas en España. MIMAM, Madrid.

Postle, M.; Foottit, A.; Fenn, T. and Salado, R. (2004), CEA: Developing a Methodology for Assessing Disproportionate Costs. Department for Environment, Food and Rural Affairs, London.

Riesgo, L. and Gómez-Limón, J.A. (2006), Multicriteria policy scenarios analysis for public regulation of irrigated agriculture. Agricultural Systems, $91(1-2): 1-28$.

Siegel, K.; Kauer, B. and Pahl-Wostl, C. (2010), Conceptualising uncertainty in environmental decision-making: the example of the EU Water Framework Directive. Ecological Economics, 69: 592-510. 